\title{
The climate change induced problems in South Asia, a case study of Bangladesh, India, Nepal, and Pakistan
}

\author{
Medani P Bhandari \\ Department of Natural Resource \& Environment / Sustainability Studies, Akamai University, USA
}

Correspondence: Medani P Bhandari, PhD is Professor at the Department of Natural Resource \& Environment/Sustainability Studies, Akamai University, Hawaii, USA, Tel 240-505-I469, Email medani.bhandari@gmail.com, mbhandar@syr.edu

Received: February 04, 2018 | Published: April 09, 2018

Copyright@ 2018 Bhandari. This is an open access article distributed under the terms of the Creative Commons Attribution License, which permits unrestricted use, distribution, and reproduction in any medium, provided the original author and source are credited.

\section{Introduction}

Recognizing the severity of the impact of global climate change, the Intergovernmental Panel on Climate Change (IPCC) in ${ }^{1}$ drew attention to the issue of vulnerability, which it defined as "the degree to which a system is susceptible to, and unable to cope with, adverse effects of climate change, including the variability and extremes...[it] is a function of the character, magnitude and rate of climate change variation to which a system is exposed, its sensitivity and its adaptive capacity". ${ }^{2}$

I argue, however, that this definition needs to be expanded if we truly are to grasp what it means to be vulnerable to climate change induced effects. The definition must account not only for physical risks and resiliency, but for the capacity of societies to mitigate those risks and respond to climate change induced crises.

The need for such an expansive understanding of vulnerability is clear when we consider that discussion of climate change issues in the media and policy forums of developed nations - especially the United States and European Union-tends to focus on the potential impacts on the economies of these nations in the future. Climate change, however, already is having devastating effects on developing nations - effects that, despite being quantified; receive virtually no attention in the Western world.

The impact of climate change and physical vulnerability to its effects has been well documented globally; in particular it is intense in the lower Himalayan developing world such as Nepal and Northern India, the effects of which translate directly to the ecosystems of the lowland and coastal islands, as in Bangladesh. ${ }^{1,3}$ Bangladesh, India, Nepal, and Pakistan already face severe problems due to rapid climate change, but these problems are utterly exacerbated by the fact that these nations are unprepared to mitigate them because of societal factors such as population growth and poverty.

\section{Keywords}

climate change, vulnerability, human development, developing nations, poverty

\section{Background}

CIA $^{4}$ estimates show that population growth in all four of these countries significantly exceeds the global average. For example, Nepal's population is growing at the rate of 1.596 percent, followed by Pakistan 1.573; Bangladesh 1.566 and India 1.344 percent, while the global growth rate is $1.1 \%$ and the rate in much of the developed world is either stable or negative. ${ }^{5}$ Further, we find that poverty in these four countries, as measured by the Human Development Index (HDI) and Multidimensional Poverty Index (MPI) is extensive (as shown in the table 1 below).

Table IA brief comparative account of four countries (including HDI and MPI Rand and Index)

\begin{tabular}{|c|c|c|c|c|c|c|c|c|c|c|}
\hline Country & $\begin{array}{l}\text { Land } \\
\text { surface } \\
\text { in } 000 \mathrm{Sq} . \\
\mathrm{Km})\end{array}$ & $\begin{array}{l}\text { Population in } \\
\text { million }\end{array}$ & $\begin{array}{l}\text { Population } \\
\text { Density (per } \\
\text { Sq.km.) } 2010\end{array}$ & $\begin{array}{l}\text { HDI } \\
\text { Rank }\end{array}$ & $\begin{array}{l}\text { HDI } \\
\text { Index }\end{array}$ & $\begin{array}{l}\text { MPI } \\
\text { Rank }\end{array}$ & $\begin{array}{l}\text { MPI } \\
\text { Index }\end{array}$ & $\begin{array}{l}\text { PPP GNI/ } \\
\text { capita (US\$) } \\
2010\end{array}$ & $\begin{array}{l}\text { GNI/capita } \\
\text { (US\$) } 2010\end{array}$ & $\begin{array}{l}\text { Annual } \\
\text { growth } \\
\text { GDP (\%) } \\
2010\end{array}$ \\
\hline Bangladesh & 144 & 160 & II 57.83 & 129 & 0.469 & 72 & 0.29 & 1550 & 580 & 6.2 \\
\hline India & 3287 & $1|8| .4$ & 350.61 & 119 & 0.519 & 73 & 0.3 & 3280 & 1,220 & 7.3 \\
\hline Nepal & 147 & 28.9 & 202.06 & 138 & 0.428 & 81 & 0.35 & 1180 & 440 & 5.3 \\
\hline Pakistan & 796 & 184 & 206.9 & 125 & 0.49 & 69 & 0.28 & 2680 & 1,000 & 2 \\
\hline
\end{tabular}

Data Source: Environmental Performance Index (EPI) 2010;World Bank 20II; UNDP 2010: 223-224; Alkire and Santos (2010) (from Multidimensional Poverty Index: 2010 Data) and OPHI 2010; CIA 2010 (Note: Human Development Index (HDI) in 0-I scale; Multidimensional Poverty Index (MPI) in 0-I scale). 
As seen in the table 1, among the 169 nations ranked by the HDI, India is $119^{\text {th }}$ (where lower rank represents better and higher rank represents worse performance), followed by Pakistan 125, Bangladesh 129 and Nepal 138 rank. These rankings correspond to HDI scores of 0.519 for India, followed by Pakistan 0.490, Bangladesh 0.469 and Nepal only 0.428 . It is an established notion that, "the Human Development Index (HDI) is a summary composite index that measures a country's average achievements in three basic aspects of human development: health, knowledge, and income" which can be enhanced only if the countries have sufficient resources and technological capacity. Similarly, in terms of MPI Pakistan ranks $69^{\text {th }}$ followed by Bangladesh at $72^{\text {nd }}$, whereas India ranks $73^{\text {rd }}$ (below Bangladesh) and Nepal ranks $81^{\text {st }}$ among 104 countries on MPI. (Higher MPI rank indicates a greater gap between and the rich and poor.)

The table reveals the limitations stem from a lack of resources and their over dependence on underdeveloped technologies. In these countries climate forecasting has been very inefficient and ineffective. Exceptional climate change has worsened the existing social and environmental problems. This has caused mass migration of both elites and agricultural workers and has yielded severe socio-economic and political ramifications.

\section{The climate change induced problems}

"Observed physical and biological impacts of recent climate change in the developing world, especially in the tropics and sub-tropics, where substantial evidence is known to exist, but poor documentation, limited accessibility, and the sheer diversity of studies and sources has so far precluded proper scrutiny and assessment". 8

Increasing vulnerability of these South Asian nations has been widely noted. ${ }^{7,910}$ For example, the UN International Strategy for Disaster Reduction (2010) identifies this region as being at the greatest risk globally with regard to climate change; Scandinavia being at lowest risk. ${ }^{11}$

In the Germanwatch report of, ${ }^{12}$ Bangladesh tops the list as the country at the greatest risk globally, followed by Nepal $\left(11^{\text {th }}\right)$, India $\left(12^{\text {th }}\right)$, and Pakistan $\left(37^{\text {th }}\right)$. It is no coincidence that countries at the greatest risk are characterized by high levels of poverty, dense populations, and inordinate exposure to climate-related events. These countries are dependent agriculture and prone to floods and drought. The severity and consequences of these risks can be seen vividly and tragically in terms of lives lost due to climate events over the period 1990-2009, as in Figure 1 below.

The Germanwatch Global Climate Risk Index (GCI) is an analysis based on the most reliable available data on the impacts of extreme weather events and associated socio-economic data. Thus, it only looks at one important piece in the overall, more comprehensive puzzle of climate-related impacts on socio-economic systems and, for example, does not take into account aspects such as sea-level rise or glacier melting...data only show the direct impacts of extreme weather events...The Climate Risk Index indicates a level of exposure and vulnerability to extreme events which countries should see as a warning signal to prepare for more severe events in the future. GCI ranks 172 , whereas lower number in rank shows extreme risk and higher rank shows lower risk. ${ }^{12}$
Overall scenario shows that all four countries are in the threat zone due to climate change, poverty, uncontrolled population growth, and weak mitigation options in their respective geographical locations. ${ }^{1}$ For example, globally, Bangladesh is recognized as one of most vulnerable countries to be impacted by global warming and climate change. This is due to its unique low level of geomorphic location, dominance of floodplains, high population density, high levels of poverty, and overdependence on primary activities for survival by the majority of the population. Similarly, Nepal is the second most vulnerable country among four due to her high vulnerability to natural disasters with raising temperature in higher elevations. ${ }^{13}$ India and Pakistan are no exceptions either. Each year natural disasters such as flood, drought, cyclone, and land slide take bring catastrophic damages taking toll of thousands of lives, houses, and large swathes of farmland. The annual monsoon rains forced reservoirs to release massive volumes of water into already burgeoning rivers, bursting banks and submerging villages and crops in low-lying areas in all four countries. ${ }^{14}$ Though the governments of the respected countries individually and collectively are aware of this severity of the climate change impacts, and have taken some mitigation initiatives; however due to the lack of technology and economic resources coupled with poor institutional arrangements, uncontrolled population growth and ever-increasing poverty have constrained them from taking effective actions.

\section{Conclusion}

Reading the prevailing attitude in the West through media reports and public policy discussion leaves one with the distinct impression that the effects of climate change are still somewhat distant and primarily economic. As a result, while Western public dialogue about climate change often reflects serious concern, it utterly fails to capture the urgency demanded by the disastrous effects already wreaking havoc on lives and economies of developing nations - a tragically ironic situation, as the global scientific consensus points to developed nations as bearing primary responsibility for the climate change effects we are witnessing globally today. A more expansive understanding of vulnerability to climate change would promote deeper appreciation globally — but especially in the West — for the meaning and impact of climate change in real terms.

As seen in this study Bangladesh, India, Nepal, and Pakistan have been facing extreme climate change induced risks, losing property and facing human causality which are quantifiable. The people of this vulnerable zone may even need to move or migrate to safer places, which also can have an impact on social wellbeing and can create the conflicts. Clearly, climate change issues cannot be addressed in isolation. They require global cooperation and also unprecedented levels of cooperation, collaboration and resource mobilization among governments, businesses, civil society groups and communities themselves. ${ }^{2}$ Existing mechanisms of cooperation need to develop special provisions to help the most vulnerable to mitigate climate change induced risks. ${ }^{15,16}$

While the consequences of climate change may not be readily apparent in the developed world, in the developing world they are tragically apparent and warrant not only a heightened sense of urgency globally, but concerted and immediate action to develop plausible solutions. 


\section{Acknowledgement}

I would like to thank to my wife and lifelong motivator, mentor Prajito Bhandari for her insightful comments, and inputs. I would also like to Mr. Peter Englot for insightful comments, input and language editing. Special thanks to Prajita, Manaslu; Prameya and Kelsey who read this paper several times provide their feedbacks and edited the language. I would also like to thank to Ms. Tatjana Capar of Ology Journals, Kft., who supported me in the publication process. Thanks to all readers as well.

\section{References}

1. IPCC, Climate Change 2007: Impacts, Adaptation and Vulnerability. Contribution of Working Group II to the Fourth Assessment Report of the Intergovernmental Panel on Climate Change. Parry ML, Canziani OF, Palutikof JP, van der PJ, Linden, Hanson CE. Cambridge University Press, Cambridge, UK. 2007;976. https://www.ipcc.ch/pdf/assessment-report/ ar4/wg2/ar4_wg2_full_report.pdf

2. United Nations Global Compact, United Nations Environment Programme (UNEP), Oxfam, and World Resources Institute (WRI): Adapting for a Green Economy: Companies, Communities and Climate Change A Caring for Climate Report. 2011 http://pdf.wri.org/adapting_for_a_green economy.pdf

3. Climate Change 2014: Mitigation of Climate Change, Summary for Policymakers, Technical Summary, Part of the Working Group III Contribution to the Fifth Assessment Report of the Intergovernmental Panel on Climate Change. 2015 https://www.ipcc.ch/pdf/assessmentreport/ar5/wg3/WGIIIAR5_SPM_TS_Volume.pdf

4. CIA: The World Factbook - Central Intelligence Agency (CIA) 2018 https://www.cia.gov/library/publications/the-world-factbook/geos/pk.html

5. Population Reference Bureau. World Population Growth, 1950-2050. Population Reference Bureau, Washington, DC, USA. 2011. http://www. prb.org/pdf11/2011population-data-sheet eng.pdf

6. Verisk Maplecroft: Climate Change Vulnerability Index. 2011 http://www maplecroft.com/about/news/natural_disasters.html https://maplecroft. com/about/news/ccvi.html

7. World Bank. South Asia and Climate Change: A Development and Environmental Issue, the World Bank, Washington, DC. 2009 http://siteresources.worldbank.org/SOUTHASIAEXT/Resources/ Publications/448813-1231439344179/5726136-1259944769176/SAR Climate_Change_Full_Report_November_2009.pdf
8. Carter Timothy R. Assessing impacts of climate change: an editorial essay. Wiley Interdisciplinary Reviews: Climate Change. 2011;1(4):479-482.

9. UNISDR. Living with Risk, A global review of disaster reduction initiatives. 2004 version, Inter-Agency Secretariat of the International Strategy for Disaster Reduction (UN/ISDR), New York. 2004. https:// www.unisdr.org/files/657_lwr1.pdf

10. PRB: Human Population- Population Growth. 2009 http://www.prb.org/ Publications/Lesson-Plans/HumanPopulation/PopulationGrowth.aspx

11. PRB: Human Population: Population Growth: Teacher's Guide. 2009 http://www.prb.org/Educators/TeachersGuides/HumanPopulation/ PopulationGrowth.aspx

12. Germanwatch eV:Global Climate Risk Index. 2013 https://germanwatch. org/en/download/7170.pdf

13. Yohe G, Malone E, Brenkert A, et al. A Synthetic Assessment of the Global Distribution of Vulnerability to Climate Change from the IPCC Perspective that Reflects Exposure and Adaptive Capacity. Palisades, New York: CIESIN (Center for International Earth Science Information Network), Columbia University. (2006) http://sedac.ciesin.columbia.edu/ mva/ccv/ Yohe GE, Malone A, Brenkert M, Schlesinger H, Meij X, Xing. Global Distributions of Vulnerability to Climate Change. The Integrated Assessment Journal. 2006:6(3):35-44. http://journals.sfu.ca/int assess/ index.php/iaj/article/viewFile/239/210[access 2/16/2018]

14. German Watch: The Climate Change Performance Index- Results. (2012) https://germanwatch.org/klima/ccpi10.pdf (see also) German Watch: The Climate Change Performance Index: Results. 2010 http://germanwatch. org/de/download/1632.pdf

15. USAID. Country Assistance Strategy Nepal (2009 - 2013) U.S. Agency for International Development, U.S. Mission to Nepal, Kathmandu, Nepal. 2009. http://pdf.usaid.gov/pdf_docs/PBAAB537.pdf

16. UNESCAP: Statistical Yearbook for Asia and the Pacific. 2009 http:// www.unescap.org/stat/data/syb2009/ESCAP-SYB2009.pdf

17. Bhandari Medani P. Environmental Performance and Vulnerability to Climate Change: A Case Study of India, Nepal, Bangladesh, and Pakistan. Climate Change and Disaster Risk Management. 2012;149-167.

18. Bhandari Medani $\mathrm{P}$, Bhattarai Keshav. Institutional Architecture for Sustainable Development: A Case Study from India, Nepal, Bangladesh, and Pakistan. ARMG Publishing. 2017;1(3):6-21. 